\title{
Passive house as temporary housing after disasters
}

\author{
F. Nocera ${ }^{1}$, F. Castagneto ${ }^{1}$, A. Gagliano ${ }^{2}$ \\ ${ }^{1}$ Department of Civil Engineering and Architecture \\ University of Catania \\ Viale Andrea Doria n.6 - 95125, Catania (Italy)
}

Phone/Fax number:+0039 095 7382366, e-mail: francesco.nocera@unict.it

${ }^{2}$ Department of Electrical, Electronics and Computer Engineering

University of Catania

Viale Andrea Doria n.6 - 95125, Catania (Italy)

Phone/Fax number:+0039 095 7382450, e-mail: antonio.gagliano@dieei.unict.it

\begin{abstract}
Natural disasters, such as earthquake, devastate cities, communities, and families in seismic regions. People, who have endured these catastrophes, have often nowhere to go and they are often guested into shelters or substandard housing. These people leave in conditions that are often far from ideal and what is initially presented as a housing solution for a week or two can quickly turn into a housing for several months or more.

This study deal with a design of passive house as post disaster shelter which is developed through the modelling and simulation of energy consumption, thermal performance and net carbon emissions. The temporary housing is designed for the warm Mediterranean climate (Csa), but the method can be attuned to other climates or geographical contexts. The aim of this study is to trace a guideline for shelter with a low environmental impact that could be built quickly, easily and provides a comfortable living environment reducing the need for active systems, such as electricity, air conditioning, and heating through passive design also over long time after the disaster.
\end{abstract}

Key words. passive house, earthquake, disaster, energy, performance

\section{Introduction}

2.

In the world today, the severity of natural disasters such as earthquakes, seaquakes, landslides, floods are increasing. In 2016, there were a number of large-scale disasters across the world, including earthquakes in Japan, Ecuador, Tanzania, Italy and New Zealand. There were also a number of severe floods in the US and across Europe and Asia, and a record high number of weather events in the US [1]. In total, the natural disaster events were 191 in 2016. Globally, approximately 7,000 people lost their lives or went missing in disasters. In particular, in Europe, the territory exposed to a high level of natural catastrophe risks, due to its natural characteristics and anthropological factors are the Italian regions. On 24 August 2016, a magnitude 6.2 earthquake hits the Apennines Mountains in central Italy, killing 299 people and devastating the small towns of Amatrice, Accumoli and Pescara del Tronto. Italy has a long history of damaging earthquakes. In 1908, Messina in Sicily was hit by a magnitude 7.5 earthquake and tsunami that claimed about 86,000 victims, making it the deadliest earthquake documented in Europe. A few years later, in 1915 a magnitude 7.0 quake struck the same area as the 2016 shakes, killing more than 30,000 people. Since 1900 , earthquakes have caused around 160,000 deaths in Italy, while since the Second World War alone, there have been 1,061 lethal landslides, and at least 672 fatal floods. Hydrogeological events have claimed over 9,000 lives, with over 700,000 people left displaced and homeless. In table I are reported the most important Italian Earthquake based on Emergency Events Database (EM-DAT) of The Center for Research on the Epidemiology of Disasters [2]

Table I. - The most important Italian Earthquakes

\begin{tabular}{|c|l|c|c|}
\hline Date & Location & Richter Scale & Deaths \\
\hline $08 / 09 / 1905$ & Calabria & 7.9 & 2,500 \\
\hline $18 / 06 / 1906$ & Naples & 8.3 & 700 \\
\hline $28 / 12 / 1908$ & Messina,Reggio & 7.5 & 86,000 \\
\hline $13 / 01 / 1915$ & Avezzano & 7.0 & 29,980 \\
\hline $23 / 07 / 1930$ & Naples & 6.5 & 1,883 \\
\hline $18 / 03 / 1944$ & Naples & & 26 \\
\hline $15 / 011968$ & Belice Valley & 6.3 & 224 \\
\hline $06 / 02 / 1971$ & Toscana & 4.6 & 22 \\
\hline $06 / 05 / 1976$ & Friuli & 6.5 & 922 \\
\hline $09 / 091976$ & Friuli & 6.5 & 12 \\
\hline $16 / 04 / 1978$ & Sicily & 6.1 & 5 \\
\hline $19 / 09 / 1979$ & Val Nerina & 5.9 & 5 \\
\hline $23 / 11 / 1980$ & Avellino & 7.2 & 4,689 \\
\hline $14 / 02 / 1981$ & Avellino & 4.9 & 12 \\
\hline $13 / 12 / 1990$ & Carlentini (Sicily) & 4.7 & 19 \\
\hline $26 / 09 / 1997$ & Umbria, Marche & 5.5 & 14 \\
\hline $31 / 10 / 2002$ & Molise & 5.4 & 30 \\
\hline $06 / 04 / 2009$ & Aquila & 6.3 & 295 \\
\hline $20 / 05 / 2012$ & Finale Emilia & 6 & 7 \\
\hline $29 / 05 / 2012$ & Modena & 5.8 & 17 \\
\hline $24 / 08 / 2016$ & Amatrice & 6.2 & 296 \\
\hline
\end{tabular}

Analyzing the global number of natural disasters from the EM-DAT database, it can be observed that while the number of natural disasters has remained relatively lowfrequency between 1900-1940, they have increased exponentially from the year 1980 . Moreover, it can be highlighted that the most event are prevalently localized in the south regions of Italy. As it is well known, most of the 
natural disasters cause collapse of housing. Therefore, temporary shelters need to be provided to population in a very short period of time. Indeed, the immediate need that arises following a disaster is a comfortable shelter and safe temporary housing. Various countries employ different types of construction approaches and materials for the construction of temporary housings and shelter which lead to different results in terms of construction duration and comfort as well as satisfaction of the population. Although there have been many different types of temporary housing around the world, an ideal solution, which particularly satisfy all the needs of population, still has not been found [3] [4]. After a disaster the needs for housing is a fundamental step to establish some sense of normality in the life of population and to guarantee comfort, privacy, protection against external factors and better health conditions for people because losing a house is more than a physical deprivation, it is losing dignity, identity and privacy [5]. Past cases of temporary housing from across the world and especially in Italy reveal that what initially starts as a temporary shelter or housing for a short period of time may end up being used for many years following the disaster, years to even decades in some cases [6]. It is interesting to underline a particular case of temporary housing realized in Messina after the earthquake of the year 1908, which are partially still standing nowadays (Fig.1).

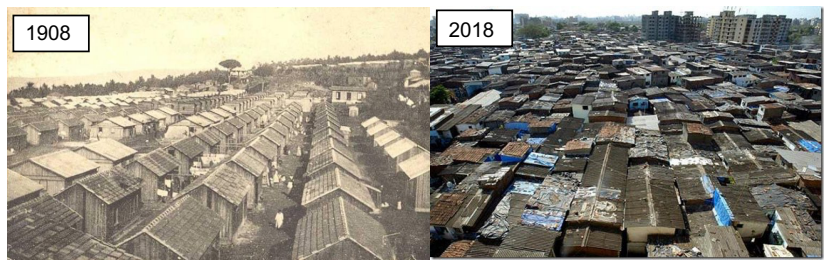

Fig.1: Temporary housing in Messina (Sicily)

In this case the temporary housing became permanent housing. They are not exactly the same as they were in the past, although in some cases they still are. It is worthwhile remembering that a 2009 Italian parliamentary inquiry into the matter, estimated that there were still 3,100 shanties present in the Messina territory and 12,000 people living in them [7] [8]

\section{Temporary housing types}

Temporary housing types are mainly prefabricated, massproduced and standardized and they can be classified into two general categories: prefabricated ready-made units and kit supplies. The ready-made units are prefabricated housing solutions completely assembled in factory which can be more quickly installed after a disaster thanks to their preconstruction but need heavy transport systems. On the other hand, kit supplies facilitates transportation and the local assembly, since the elements that constitute the unit are small, light and easy to handle but require the participation of local people in the construction and/or assembly process [9]. In Figure 2 are showed some solution of prefabricated ready-made units and kit supplies, installed at Amatrice Town after the earthquake.

The most recent experiments see the work of Shigeru Ban at the center of attention, which proposes for the refugee emergency a realizable house with three different building systems: the cardboard, the Timber Frame wooden structure and the blocking of raw earth blocks, the masonry in compressed blocks of raw earth. In this way it allows the end user to choose the system to be implemented in self construction. [33]

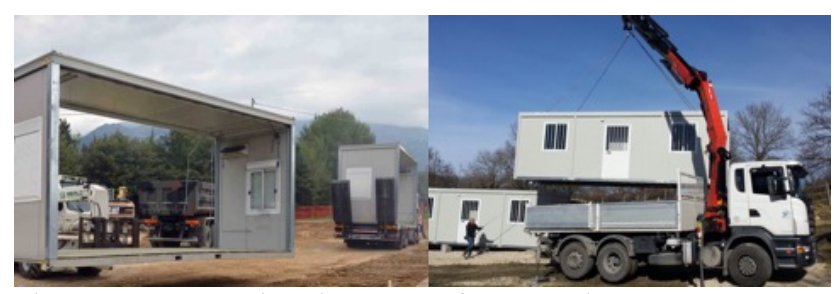

Fig. 2 : Temporary housing types after Amatrice

\section{The design model}

One of the most critical issues after a disaster is the gap between short-term needs (emergency or temporary shelter) and long-term needs (permanent housing). In most cases, the process of achieving permanent accommodation takes years for various reasons, such as the removal of rubble and finding suitable and safe space on which reconstruction can take place. During this time, people are housed in temporary accommodation, where they try to return to their previous lifestyle and resume their activities. The main purpose of this study is to present a novel design of a low energy housing, realized with the use of plantbased and earth material, which can be "adaptable" to the specific context of the emergency as well as be able to guarantee comfort, privacy, protection and well-being conditions. To achieve that objectives, it is necessary a "modular design" conceived on building systems made by natural materials which need very low energy and low cost. Modular design is based on the dimensions of a building component defined 'module', used as a unit of measurement or standard which as a result determines the proportions of the remaining construction. The proposed temporary housing is based on the proportions of the bee cells. All other dimensions of that building system evolved around the bee cells, resulting in a systematic architecture, scaled and proportioned. The idea of using hexagon as modular element comes from is ability to be replicable without using other geometric figures.

The idea of module design is focused mainly on the comfort, the energy efficiency, the environment sustainability and the low-cost. Consequently, the following factor were considered:

1) Functional: the starting point is based on practicality and the solidness. The module is thought as a correlated union of base units, that can work independently. The principle of functional flexibility is an essential element to the function of module.

2) Structural: the possibility of connection between the modules is a basic and distinctive element because perform the critical role, necessary after a disaster, of the encouragement to the socialization, aggregation and sharing

3) Environmental: materials choices have been made considering not only the thermal comfort, health, safety, cost and maintenance but also their potential contributions to reduce impact on Climate Change.

4) Transportation: the structure of the module is thought trying to contain the lowest possible number of different 
elements to favor various connection modalities that can be realized without specific tools. Consequently, the dry assembling is the right choice to reach the previously target. Figure 4 shows the schematic design of the module. It can be combined as a honey cell with different size and configuration. The design concept is formulated considering respectively: the single unit layout, the horizontally aggregation of dwellings, the adaptability of the building systems to the specific context. Regarding the internal layout, each space is equipped with minimum furniture needed, considering that emergency end-users do not hold any belongings.

\begin{tabular}{|c|c|c|}
\hline Configuration & Area & Occupants \\
\hline & $41 \mathrm{~m}^{2}$ & one person \\
\hline & $82 \mathrm{~m}^{2}$ & Two people \\
\hline & $123 \mathrm{~m}^{2}$ & Three people/ one family \\
\hline
\end{tabular}
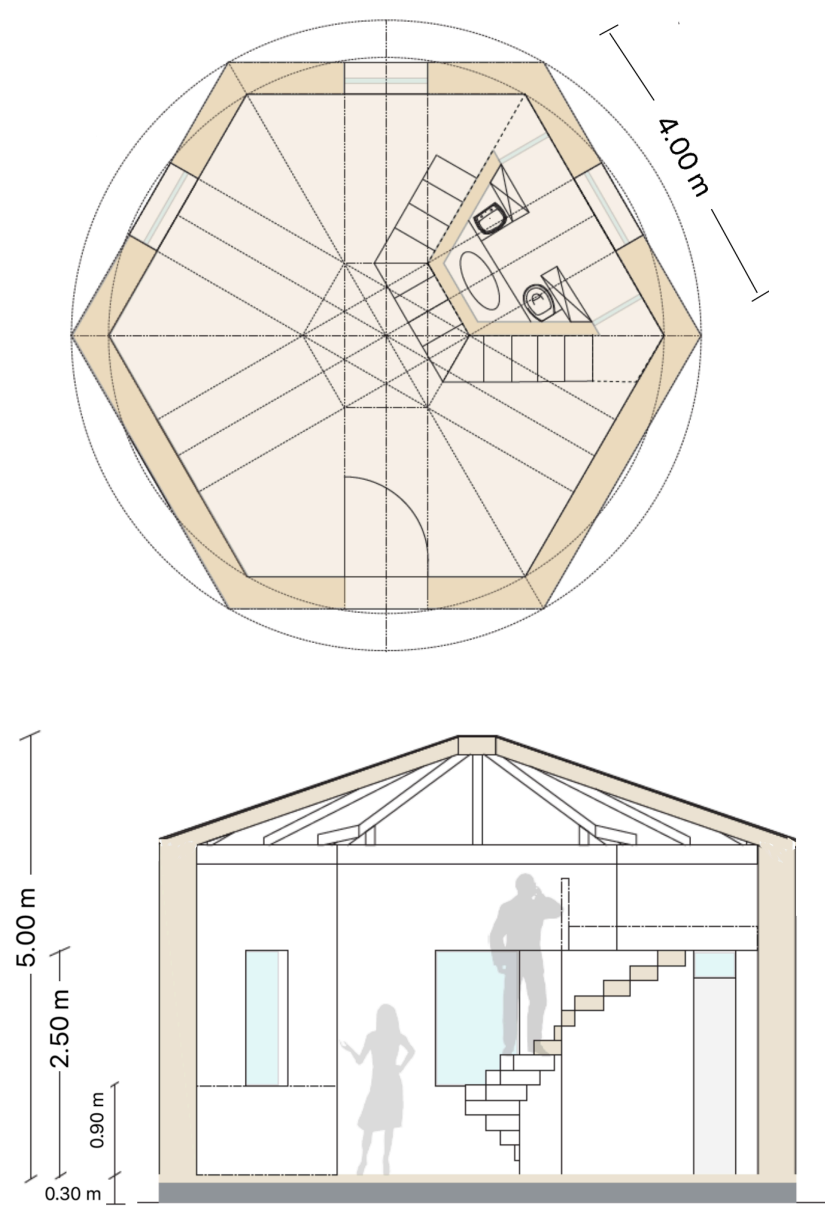

Fig. 4. schematic design of the module and configurations

Therefore, the furniture must be provided with the dwelling. Moreover, it should be installed appliance with an elevated energy class and LED light [10] to reduce the energy demand which can be satisfied by renewable energy source (photovoltaic and solar) [11] and handle all wastewater and storm-water on-site. The module is designed on the Passive House standard because it needs very little energy for heating, ventilation and air- conditioning purposes in order to achieve indoor thermal comfort conditions and low heating and cooling energy requirement, compared with typical contemporary buildings. Specifically, Passive Houses require less than 15 $\mathrm{kWh} / \mathrm{m}^{2} \mathrm{y}$ for heating or cooling and the heating or cooling peak load is limited to a maximum of $10 \mathrm{~W} / \mathrm{m}^{2}$. In order for a building to be considered as a Passive House, its conventional primary energy use must not exceed 120 $\mathrm{kWh} / \mathrm{m}^{2} \mathrm{y}$. In addition, a recycling and reuse system of water provides to collect and use rainwater for everything

\section{Description of the model}

The module has a shape of a hexagon with external dimension late $4.00 \mathrm{~m}$ and apothem $3.44 \mathrm{~m}$. The total heated floor area is $37.74 \mathrm{~m}^{2}$ and the total heated volume is $173.54 \mathrm{~m}^{3}$. The shape factor $(\mathrm{Fs}=\mathrm{A} / \mathrm{V})$ of the model is 0.21 $\mathrm{m}^{-1}$.

\section{A. Construction}

Cross-Laminated Timber (CLT), also known as "CrossLam" or "X-Lam" technology is becoming very popular among the designers of passive house. The CLT construction system is based on the use of large multi-layer panels made from lumber boards that are glued together, alternating the direction of their fibers for each layer, which improves rigidity, stability, and mechanical properties. The cross-laminated nature of the panels implies that they can take up forces in all directions, which allows them to be used as walls, slabs or roofs, in a wide range of applications. Moreover, CLT technology guarantees simple and fast onsite construction process, providing excellent air tightness and high thermal insulation [12]. The structural technology adopted for the housing unit module is based on a commercial cross-laminated timber panel (X-Lam). The vertical envelope is self-supporting structure with insulation layers placed in the inner and outer side (Figure 5). The insulation is guaranteed by natural, plant-based materials as straw, cork, corn fiber while cob plaster is used as external plastering. The $\mathrm{U}$-value is $0.138 \mathrm{~W} \mathrm{~m}^{-2} \mathrm{~K}^{-1}$ for exterior wall, $0.116 \mathrm{~W} \mathrm{~m}^{-2} \mathrm{~K}^{-1}$ for the floor slab, $0.104 \mathrm{~W}$ $\mathrm{m}^{-2} \mathrm{~K}^{-1}$ for the roof.
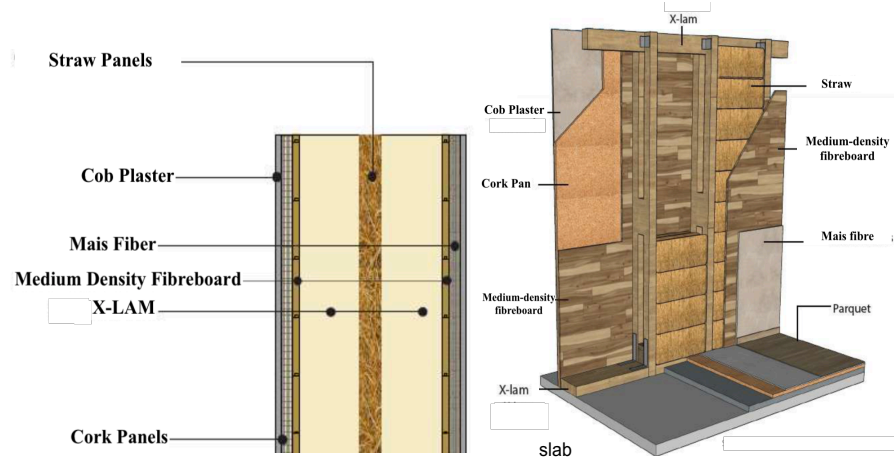

Fig. 5. Stratigraphy of the walls.

The composition wall element and of other analyzed external wall elements is listed in Tables II. The U-value of building wall reported in Table II complies with the Italian Regulation on the whole Italian territory [13] [14] 
Table II. - thermal properties of the walls

\begin{tabular}{|c|c|c|}
\hline Layer & $\begin{array}{c}\mathrm{S} \\
(\mathbf{m})\end{array}$ & $\begin{array}{c}\mathbf{K} \\
\left(\mathbf{W} \mathbf{m}^{-2} \mathbf{K}^{-1}\right)\end{array}$ \\
\hline Outer Plaster & 0.020 & 0.050 \\
\hline Cork Panel & 0.025 & 0.040 \\
\hline MDF & 0.015 & 0.050 \\
\hline Straw Panels & 0.300 & 0.062 \\
\hline MDF & 0.015 & 0.050 \\
\hline Mais Fiber & 0.025 & 0.035 \\
\hline Inner Plaster & 0.010 & 0.050 \\
\hline Total thickness & \multicolumn{2}{|c|}{$0.409 \mathrm{~m}$} \\
\hline U-Value & \multicolumn{2}{|c|}{$0.138 \mathrm{~W} \mathrm{~m}^{-1} \mathrm{~K}^{-1}$} \\
\hline
\end{tabular}

\section{B. Glazing}

A window glazing with three layers of glass, two lowemissive coatings and krypton in the cavities for a normal configuration of 4E-12-4-12-E4, was considered. The glazing configuration with a g-value of $48 \%$ and $\mathrm{Ug}=0.51$ $\mathrm{W} \mathrm{m}{ }^{-2} \mathrm{~K}^{-1}$ assures a high level of heat insulation and light transmission [15] [16]. The window frame $\mathrm{U}$-value is $\mathrm{Uf}=$ $0.85 \mathrm{~W} \mathrm{~m}^{-2} \mathrm{~K}^{-1}$. The glazing-to-wall area ratio (AGAW) for the four windows is $17.6 \%$.

\section{Climate and orientation}

The energy analysis suppose that the temporary housing unit is located in two Mediterranean localities characterized by different HDD: Catania (climate zone B - HDD 833) and Enna (climate zone E - HDD 2248). They are representative of a meaningful sample of the extreme climatic conditions of Italian municipalities. Catania has a typical Mediterranean Climate with hot, dry summers and moderately cool, wet winters. In summer months, the average outdoor temperature ranges from $20^{\circ} \mathrm{C}$ to $35^{\circ} \mathrm{C}$, with peaks of $40{ }^{\circ} \mathrm{C}$ when the sirocco winds blow from North Africa. In winter, the outdoor temperature varies from $5{ }^{\circ} \mathrm{C}$ to $15^{\circ} \mathrm{C}$, while in spring and autumn the climate is mild and the temperatures vary from $10^{\circ} \mathrm{C}$ to $28^{\circ} \mathrm{C}$. Enna has dry-summer subtropical climate. In summer months, the average outdoor temperature ranges from $10.0{ }^{\circ} \mathrm{C}$ to $21.9^{\circ} \mathrm{C}$. In winter, the outdoor temperature varies from -3 ${ }^{\circ} \mathrm{C}$ to $10{ }^{\circ} \mathrm{C}$, while in spring and autumn the climate is mild and the temperatures vary from $7^{\circ} \mathrm{C}$ to $18^{\circ} \mathrm{C}$. [17]

The study was performed in different climate zone to verify if the module achieves the Passive House Standard without any modification or with small simple changes.

\section{Shading}

The Passive house was initially designed using a heliodon to determine how the sun's rays shines on the house any time, day, and month of the year. It was designed with a south-oriented. An adequate roof overhang was designed for shading windows and reducing the amount of rain that hits siding, windows, and doors. [18].

\section{E. Internal gains, HVAC and renewable systems}

The house was equipped with a HVAC system certificated by Passive House Institute. The system allows a ventilation with heat recovery unit and sanitary hot water production. The heat pump is able to produce hot water and contributes to heating the supply air. The heat pump is equipped with a reversible cooling circuit, so that in the summer it can cool the intake air while it also producing hot water. The remaining energy needs is supplied via other renewable energy sources, such as thermal and/or photovoltaic panels with battery storage systems in order to attained an energy independence [19]. It was installed as heat pump the model NILAN A/S certified by PHI [20][21][22], with a nominal power $6.00 \mathrm{~kW}$ (SCOP 5.11). The volume of hot water tank is 180 liters. The mechanical ventilation system is guaranteed by the model ComfoAir ERV, with an efficiency of $88 \%$ heat recovery, certified by PHI [20]. The air exchange by the windows is $0.33 \mathrm{ac} / \mathrm{h}$. As for the night ventilation, the exchange is $1.30 \mathrm{ac} / \mathrm{h}$. For night ventilation, all windows were considered open to allow greater heat exchange, for the hottest period of the year. A thermal solar system with a gross area of $3.00 \mathrm{~m}^{2}$ provides the energy needs for domestic hot water (DHW) and a PV plant of 1.9 $\mathrm{kWp}$ supplies $3,143.68 \mathrm{kWh}$.

\section{F. Construction schedules}

In this section, it is reported a scheduling construction activity (Fig.7) for a single housing unit which involves chronologically durations and procedures necessary to ensure the works are completed in a way that optimizes cost, timeframe and quality. The schedule is thought to be understandable, especially to those will be involved in carrying out the construction works. Time is the basic variable in scheduling construction works especially after a disaster. The schedule will be used to determine the optimal order for the execution of activities.

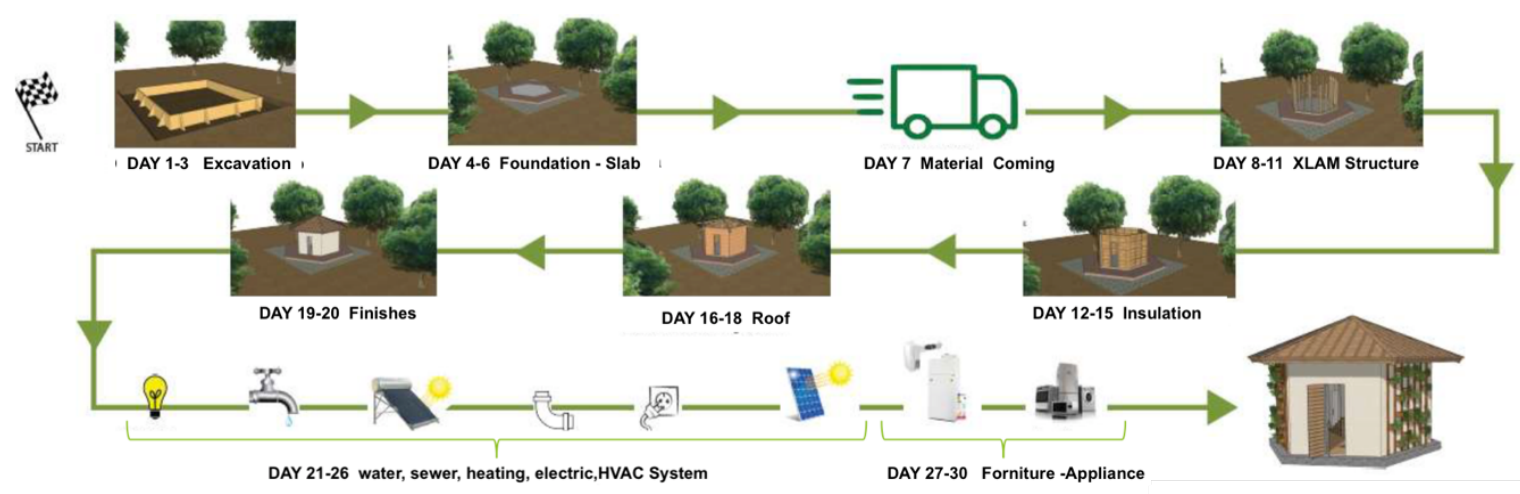


Fig. 7. scheduling construction activities

\section{Results}

According to the thermal balance obtained using PHPP tool the annual heating demand is $3 \mathrm{kWh} /\left(\mathrm{m}^{2} \mathrm{y}\right)$ for Catania and $13 \mathrm{kWh} /\left(\mathrm{m}^{2} \mathrm{y}\right)$ for Enna. The annual cooling demand is 12 $\mathrm{kWh} /\left(\mathrm{m}^{2} \mathrm{y}\right)$ for Catania and $6 \mathrm{kWh} /\left(\mathrm{m}^{2} \mathrm{y}\right)$ for Enna. The previous values comply the maximum allowed by the passive house which is $15 \mathrm{kWh} /\left(\mathrm{m}^{2} \mathrm{y}\right)$.

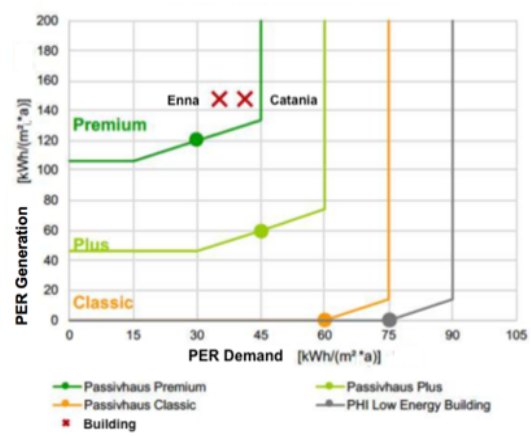

Fig. 6. Primary Energy Renewable - (PER)

The specific primary energy demand [23], which is the total energy to be used for all domestic applications (heating, hot water preparation and household electricity) was 62 $\mathrm{kWh} /\left(\mathrm{m}^{2} \mathrm{y}\right)$ for the Catania and $64 \mathrm{kWh} /\left(\mathrm{m}^{2} \mathrm{y}\right)$ for Enna. The latter values are lower of the maximum limit allowed by passive house certification that is $120 \mathrm{kWh} /\left(\mathrm{m}^{2} \mathrm{y}\right)$. The total $\mathrm{CO}_{2}$ equivalent emissions generated is lower $15 \mathrm{~kg}$ $/ \mathrm{m}^{2} \mathrm{y}$ for both localities. The results obtained with the PHPP9 Tool confirm that it is possible to realize a passive house as temporary housing using natural and ecosustainable materials reaching the level Passivhaus Premium

\section{G. Net carbon emissions and Economic Feasibility}

A Life-cycle assessment technique, to evaluates environmental impacts associated with all the stages of a product's life, was used to calculate the carbon footprint considering the GHG emissions caused by whole operational processes, transportation and activities for the materials used in the construction. The carbon footprint was calculated with a tool called One Click [24][25], which is an automated LCA tool developed by Bionova. The tool complies with the international standards on LCA study EN 15978 for European markets with CML-IA 2012 methodology. The embodied carbon in materials and material production processes was calculated according to ISO 14020 and ISO14040, as well as ISO 14025. The embodied $\mathrm{CO}_{2}$ includes energy consumption of building materials and products, the use of raw materials and greenhouse gases. In the calculations the greenhouse gases are transformed to $\mathrm{CO}_{2}$ equivalents by using IPCC's characteristic factors, in which the corresponding factors for $\mathrm{CH}_{4}$ and $\mathrm{N}_{2} \mathrm{O}$ are 25 and 298, respectively. The sum of these represent the $\mathrm{CO}_{2}$ emissions originated by embodied energy of building materials and products [26]

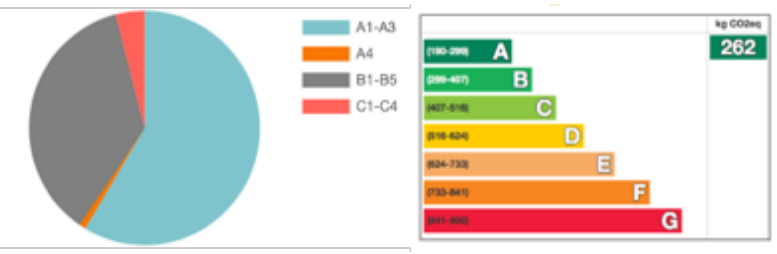

Fig.8. Embodied carbon by life-cycle stage and Embodied carbon benchmark

Only the results regarding "Global Warming Potential" (GWP) were analyzed for room reason. The carbon footprint is $262 \mathrm{~kg} \mathrm{CO}_{2}$ eq/year. The value of $56 \%$ of the total emission of $\mathrm{kg} \mathrm{CO}_{2 \text { eq }}$ is released during the manufacturing module [A1-A3] of the raw materials. The end of life [C2$\mathrm{C} 4]$ and use stage [B1-B4] are characterized by $1 \%$ and $36 \%$ of total emission. The Economic Feasibility was performed and analyzed comparing the energy consumption of Italian Reference Buildings with the passive house performance [27].The economic analysis is developed considering the initial investment cost and long-term energy cost saving effect. In particular, analysis was carried out on the energy-saving effect of various measures to improve the performance of the single family house to reach that of the passive house. The cost of the single passive housing unit is 57,000 euro which is obtained from market analysis and Italian Price List considering the building ready to use. The reference building considered is a single family house which is based on IEE TABULA [28]. The Italian reference building was used as data source for estimating and evaluating the energy savings and the $\mathrm{CO}_{2}$ emission reductions. The annual heating energy consumption of the reference building is estimated at $52.25 \mathrm{kWh} / \mathrm{m}^{2}$.year [29] [30] which is 3.45 times higher than the passive house standard $\left(15 \mathrm{kWh} / \mathrm{m}^{2}\right.$ year $)$. The service life and maintenance costs of the energy efficiency measures, and their components have been obtained according to the UNI EN 15459:2008, and the technical-economic situation in Italy was referred to the year 2018. The operating costs were evaluated according to the Italian scenario by assuming the unit cost of natural gas equal to $0.10 € / \mathrm{kWh}$ and the unit cost of electricity equal to $0.24 € / \mathrm{kWh}$ [31] . In particular, the following financial indices have been evaluated: the Net Present Value (NPV), taking into account the discount rate $r$ equal to $3.00 \%$ according Bank Italia Report [32]; the Internal Rate of Return (IRR), which is the discount rate that makes NPV of all cash flows from the investment equal to zero; the Payback Period (PP ), which is the time required after an investment to recoup the initial costs of that investment; and the Discounted Payback Period (DPP) which is used to determine the profitability of a project. In Table 3, all calculated financial indices are summarized. The previous indices confirm the economic feasibility and convenience of the passive temporary housing unit to be used for many years following the disaster events 
[13] S. Bergero, P. Cavalletti, and A. Chiari, "Energy refurbishment in existing buildings: Thermal bridge correction according to DM 26/06/2015 limit values," in Energy Procedia, 2017.

Table III. Economic Indices

\begin{tabular}{|l|l|}
\hline \multicolumn{2}{|l|}{ Ecomomic Indices } \\
\hline NPV(€) & 53,095 \\
\hline IRR (\%) & 10.52 \\
\hline PP (y) & $\mathbf{7 . 6 9}$ \\
\hline DPP (y) & $\mathbf{9 . 4 1}$ \\
\hline
\end{tabular}

\section{Conclusions}

This study shows the undeniable importance of temporary housing in helping affected population to re-establish their normal life activities in a post-disaster situation. It is necessary to look at temporary housing from the standpoint of the users, focusing more on house as the space people inhabit which can be "adaptable" to the specific context of the emergency as well as be able to guarantee comfort, privacy, protection and well-being conditions also over many years after the disaster.

\section{References}

[1] "Natural catastrophes and man-made disasters in 2016: a year of widespread damages," Swiss Re Institute, 2017. . EM-DAT, "The International Disaster Database," Centre for Research on the Epidemiology of Disasters. 2015.

[3] R. H. Kronenburg, "Mobile and Flexible Architecture: Solutions for shelter and rebuilding in disaster," blue Archit. 09 proceedings IUAV Digit. Libr., 2009.

[4] C. Johnson and G. Lizarralde, "Post-disaster housing and reconstruction," in International Encyclopedia of Housing and Home, 2012.

[5] S. Barakat, "Housing reconstruction after conflict and disaster," Humanit. Pract. Netw., 2003.

[6] G. Zhang, S. Setunge, and S. van Elmpt, "Using Shipping Containers to Provide Temporary Housing in Post-disaster Recovery: Social Case Studies," Procedia Econ. Financ., 2014.

[7] D. Farinella and P. Saitta, "The earthquake and the shanty: Post-disaster social order in a sicilian town (1908-2013)," Res. Urban Sociol., 2016.

[8] F. Navidi and A. Andalib, "Social Issues in Post Disaster Reconstruction Planning," Int. J. Archit. Urban Dev., 2013.

[9] S. Giuffrida, F. Gagliano, F. Nocera, and M. R. Trovato, "Landscape assessment and economic accounting in wind farm programming: Two cases in sicily," Land, 2018.

[10] F. Nocera, A. Lo Faro, V. Costanzo, and C. Raciti, "Daylight performance of classrooms in a mediterranean school heritage building," Sustain., 2018.

[11] Gagliano Antonio and Nocera Francesco, "Analysis of the performances of electric energy storage in residential applications," Int. J. HEAT Technol., vol. Vol.35, pp. s41-s48, 2017.

[12] F. Nocera, A. Gagliano, and M. Detommaso, "Energy performance of cross-laminated timber panel (X-Lam) buildings: A case study," Math. Model. Eng. Probl., 2018.
V. Corrado, I. Ballarini, D. Dirutigliano, and G. Murano, "Verification of the New Ministerial Decree about Minimum Requirements for the Energy Performance of Buildings," in Energy Procedia, 2016. A. Gustavsen and B. P. Jelle, "State-of-the-Art Highly Insulating Window Frames - Research and Market Review," Sintef, 2007.

B. P. Jelle, A. Hynd, A. Gustavsen, D. Arasteh, H. Goudey, and R. Hart, "Fenestration of today and tomorrow: A state-of-the-art review and future research opportunities," Solar Energy Materials and Solar Cells. 2012.

[17] S. Agrometerology, "Sicilian Data Meteorology," 2019. .

[18] J. Mlakar and J. Štrancar, "Overheating in residential passive house: Solution strategies revealed and confirmed through data analysis and simulations," Energy Build., 2011.

[19] V. Costanzo, G. Evola, L. Marletta, and F. Nocera, "The effectiveness of phase change materials in relation to summer thermal comfort in air-conditioned office buildings," Build. Simul., 2018.

[20] PHI, "Criteria for the Passive House, EnerPHit and PHI Low Energy Building Standard," 2016.

[21] W. Feist, J. Schnieders, V. Dorer, and A. Haas, "Reinventing air heating: Convenient and comfortable within the frame of the Passive House concept," Energy Build., 2005.

[22] U. Y. A. Tettey, A. Dodoo, and L. Gustavsson, "Design strategies and measures to minimise operation energy use for passive houses under different climate scenarios," Energy Effic., vol. 12, no. 1, pp. 299-313, 2019.

[23] A. Gagliano, F. Nocera, F. Patania, and G. Capizzi, “A case study of Energy Efficiency Retrofit in social housing units," in Energy Procedia, 2013, vol. 42, pp. 289-298.

[24] A. Vigovskaya, O. Aleksandrova, and B. Bulgakov, "Life Cycle Assessment (LCA) of a LEED certified building," in IOP Conference Series: Materials Science and Engineering, 2018.

[25] Bionova, “One Click LCA,” 2019. [Online]. Available: https://www.oneclicklca.com.

[26] T. Barker, "Climate Change 2007 Synthesis Report: An Assessment of the Intergovernmental Panel on Climate Change," 2007.

[27] A. Boqvist, C. Claeson-Jonsson, and S. Thelandersson, "Passive House Construction - What is the Difference Compared to Traditional Construction?," Open Constr. Build. Technol. J., 2010.

[28] V. Corrado, I. Ballarini, and S. P. Corgnati, "Typology Approach for Building Stock energy Assessment (TABULA)," Natl. Sci. Rep., 2014.

[29] Istat, "Il futuro demografico del Paese," Istat.it, 2018.

[30] C. Buratti, F. Asdrubali, D. Palladino, and A. Rotili, "Energy performance database of building heritage in the Region of Umbria, Central Italy," Energies, 2015.

[31] GSE, "GSE energy data," 2019.

[32] G. de Blasio, S. De Mitri, A. D’Ignazio, P. Finaldi Russo, and L. Stoppani, "Public guarantees to SME borrowing. A RDD evaluation," J. Bank. Financ., 2018.

[33] F. Castagneto, "S.A.F.E. Una sperimentazione progettuale per l'emergenza" in Agathòn 4/2018, Demetra Ce.Ri.Med. Palermo University Press, p.169. 